\section{(A) Check for updates}

Cite this: Dalton Trans., 2019, 48, 6767

Received 12th September 2018, Accepted 18th March 2019

DOI: 10.1039/c8dt03696a

rsc.li/dalton

\title{
Exploring transition metal fluoride chelates - synthesis, properties and prospects towards potential PET probes $\uparrow$
}

\author{
Philip J. Blower, (DD ${ }^{a}$ William Levason, (D) ${ }^{\mathrm{b}}$ Sajinder K. Luthra, ${ }^{c}$ Graeme McRobbie, (D) ${ }^{c}$ \\ Francesco M. Monzittu, (D)*b Thomas O. Mules, ${ }^{\mathrm{b}}$ Gillian Reid (D) ${ }^{\mathrm{b}}$ and \\ M. Nadeem Subhan ${ }^{\text {b }}$
}

\begin{abstract}
The coordination chemistry of the first row transition metal trifluorides with terpy $\left(2,2^{\prime}: 6^{\prime}, 2^{\prime \prime}\right.$-terpyridine) and $\mathrm{Me}_{3}$-tacn (1,4,7-trimethyl-1,4,7-triazacyclononane) was explored to identify potential systems for ${ }^{18} \mathrm{~F}$ radiolabelling. The complexes $\left[\mathrm{MF}_{3}(\mathrm{~L})\right]\left(\mathrm{M}=\mathrm{Cr}, \mathrm{Mn}, \mathrm{Fe}, \mathrm{Co} ; \mathrm{L}=\mathrm{Me} \mathrm{e}_{3}\right.$-tacn, terpy) were synthesised and fully characterised by UV-vis and IR spectroscopy, microanalysis, and, for the diamagnetic [CoF $\left.\mathrm{C}_{3}(\mathrm{~L})\right]$, using ${ }^{1} \mathrm{H},{ }^{19} \mathrm{~F}\left\{{ }^{1} \mathrm{H}\right\}$ and ${ }^{59} \mathrm{Co} N M R$ spectroscopy. Single crystal $\mathrm{X}$-ray analyses are reported for $\left[\mathrm{MF}_{3}\left(\mathrm{Me}_{3}\right.\right.$-tacn)] $(\mathrm{M}=\mathrm{Mn}, \mathrm{Co}),\left[\mathrm{FeF}_{3}(\right.$ terpy)$\left.)\right]$ and $\left[\mathrm{FeF}_{3}\left(\mathrm{BnMe}_{2}\right.\right.$-tacn)]. Stability tests on $\left[\mathrm{MF}_{3}\left(\mathrm{Me}_{3}\right.\right.$-tacn) $](\mathrm{M}=\mathrm{Cr}, \mathrm{Mn}, \mathrm{Fe})$ and $\left[\mathrm{M}^{\prime} \mathrm{F}_{3}\right.$ (terpy)] $\left(\mathrm{M}^{\prime}=\mathrm{Cr}\right.$, Fe) were performed and $\mathrm{Cl} /{ }^{19} \mathrm{~F}$ halide exchange reactions on $\left[\mathrm{CrCl}_{3}\left(\mathrm{Me}_{3}\right.\right.$-tacn)] using $\left[\mathrm{Me}_{4} \mathrm{~N}\right] \mathrm{F}$ in anhydrous $\mathrm{MeCN}$ solution, and $\left[\mathrm{FeCl}_{3}\left(\mathrm{Me}_{3}\right.\right.$-tacn)] using $\left[\mathrm{Me}_{4} \mathrm{~N}\right] \mathrm{F}$ in anhydrous $\mathrm{MeCN}$ or $\mathrm{KF}$ in aqueous MeCN solution were also carried out. Halide exchange reactions proved to be successful in forming $\left[\mathrm{FeF}_{3}\left(\mathrm{Me}_{3}\right.\right.$-tacn)] in aqueous $\mathrm{MeCN}$ solution within 30 minutes. Based upon the clean $\mathrm{Cl} / \mathrm{F}$ exchange and the good stability observed for $\left[\mathrm{FeF}_{3}\left(\mathrm{Me}_{3}\right.\right.$-tacn)] in a range of competitive media, this was identified as a possible candidate for radiolabelling. ${ }^{18} \mathrm{~F} /{ }^{19} \mathrm{~F}$ isotopic exchange was achieved by addition of ${ }^{[18} \mathrm{F}^{-} \mathrm{F}^{-}$in the cyclotron target water to a $\mathrm{MeCN}$ solution of the benzyl-substituted analogue, $\left[\mathrm{FeF}_{3}\left(\mathrm{BnMe}_{2^{-}}\right.\right.$ tacn)], at a range of concentrations down to $24 \mathrm{nM}$ with heating to $80{ }^{\circ} \mathrm{C}$ for $10 \mathrm{~min}$.; the resulting $\left[\mathrm{Fe}^{18} \mathrm{~F}^{19} \mathrm{~F}_{2}\left(\mathrm{BnMe} \mathrm{e}_{2}\right.\right.$-tacn)] shows radiochemical purity (RCP) $\geq 90 \%$ after $2 \mathrm{~h}$ in a range of formulations, including 10\% EtOH/phosphate buffered saline (PBS) and 10\% EtOH/human serum albumin (HSA). This is the first reported complex with a transition metal directly bonded to $\left[{ }^{18} \mathrm{~F}\right] \mathrm{F}^{-}$.
\end{abstract}

\section{Introduction}

$\mathrm{C}-{ }^{18} \mathrm{~F}$ based radiotracers are extensively used in positron emission tomography (PET) for imaging purposes in oncology, cardiology and neurology. ${ }^{1}$ Thousands of PET scans are performed daily on cancer patients worldwide, providing important diagnostic and clinical information. Peptides that target receptors overexpressed on the surface of the diseased cells are

\footnotetext{
${ }^{a}$ School of Biomedical Engineering and Imaging Sciences, King's College London, St Thomas' Hospital, London SE1 7EH, UK

${ }^{b}$ Chemistry, University of Southampton, Highfield, Southampton SO17 1BJ, UK. E-mail: G.Reid@soton.ac.uk,F.Monzittu@soton.ac.uk

${ }^{c}$ Pollards Wood, Nightingales Lane, Chalfont St Giles, Bucks, HP8 4SP, UK

$\dagger$ Electronic supplementary information (ESI) available: X-ray crystallographic parameters are given in Table S1. The ESI also contains UV-vis, IR and NMR spectra of the complexes, UV-vis spectra of the stability tests for $\left[\mathrm{MF}_{3}\left(\mathrm{Me}_{3}\right.\right.$-tacn) $]$ $(\mathrm{M}=\mathrm{Mn}, \mathrm{Fe})$ and $\left[\mathrm{MF}_{3}\right.$ (terpy) $](\mathrm{M}=\mathrm{Cr}, \mathrm{Fe})$, figures showing the $\pi$-stacking and $\mathrm{H}$-bonding in $\left[\mathrm{FeF}_{3}\right.$ (terpy) $]$ and $\mathrm{H}$-bonding in $\left[\mathrm{CoF}_{3}\left(\mathrm{Me}_{3}\right.\right.$-tacn $\left.)\right]$ and $\left[\mathrm{FeF}_{3}\left(\mathrm{BnMe}_{2}-\right.\right.$ tacn)], and radio and UV-traces for the radiofluorination experiments. CCDC 1860121-1860123 and 1897030. For ESI and crystallographic data in CIF or other electronic format see DOI: 10.1039/c8dt03696a
}

becoming increasingly important in diagnostic PET imaging agents. ${ }^{2}$ However, the reaction conditions for the formation of the $\mathrm{C}-{ }^{18} \mathrm{~F}$ bond are often incompatible with biomolecules (e.g. peptides). ${ }^{3}$ Organic solvents that degrade the peptide, high temperatures and competing sites for the ${ }^{18} \mathrm{~F}$-labelling reaction present in the biomolecule are the major problems encountered. As a result, often the $\left[{ }^{18} \mathrm{~F}\right] \mathrm{F}^{-}$is first incorporated into an organic molecule (prosthetic group) and then conjugated to a peptide, resulting in an increase of the total reaction time and the number of steps of the process. ${ }^{3}$ The need to improve these aspects has led to the investigation of alternative non$\mathrm{C}-{ }^{18} \mathrm{~F}$ moieties. To date, several main group elements attached to $\left[{ }^{18} \mathrm{~F}\right] \mathrm{F}^{-}$have been studied, including boron- ${ }^{4}$ aluminium- ${ }^{5,6}$ gallium- ${ }^{7,8}$ sulfur-, ${ }^{9}$ and silicon-fluoride ${ }^{10}$ systems. These are discussed in recent reviews. ${ }^{11}$ The two Group 13 metals are often coordinated to macrocyclic ligands (triazacyclononane derivatives) which confer thermodynamic and kinetic stability to the chelates and, in the case of the systems with 1,4dimethyl-7-benzyl-1,4,7-triazacyclononane ( $\mathrm{BnMe}_{2}$-tacn), the benzyl group provides a site for further functionalisation and bioconjugation. ${ }^{6,7}$ In this approach to PET radiotracers based 
on metal coordination complexes, the stability of the complex will be strongly dependant on the properties of the metal centre. The $\mathrm{M}-\mathrm{F}$ bond dissociation energy has an important role since it should be stronger compared to $\mathrm{M}-\mathrm{Cl}$, hence allowing fluorination through halide exchange reactions and, ultimately, it should be resistant in physiological conditions. Other aspects related to the metal to be considered are its size (dictating the coordination number), its redox chemistry and oxophilicity (water or anions such as phosphate should not disrupt the coordination around the metal), its Lewis acidity and its lability, allowing sufficiently rapid substitution of fluoride into the coordination sphere (when the ${ }^{18} \mathrm{~F}$ half-life of $110 \mathrm{~min}$ is considered).

We previously developed the chemistry of the Group 13 metal fluorides (Al, Ga) towards neutral nitrogen ligands and reported that radioactive ${ }^{18} \mathrm{~F}$ can be introduced into $\left[\mathrm{MCl}_{3}\left(\mathrm{BnMe}_{2}\right.\right.$-tacn $\left.)\right](\mathrm{M}=\mathrm{Al}, \mathrm{Ga})$ through $\mathrm{Cl} /{ }^{18} \mathrm{~F}$ halide exchange reactions and that $\left[\mathrm{GaF}_{3}\left(\mathrm{BnMe}_{2}\right.\right.$-tacn) $]$ can also be ${ }^{18} \mathrm{~F}$-radiolabelled through ${ }^{18} \mathrm{~F} /{ }^{19} \mathrm{~F}$ isotopic exchange using a very small amount of material $(27 \mathrm{nmol})$; both methods were successful in mild conditions, i.e. aqueous solution, room temperature or $80^{\circ} \mathrm{C}^{6,7,12} \mathrm{We}$ also investigated the transition metal fluorides using Sc(III), Y(III), La(III) and Lu(III). ${ }^{13}$ Among these d- and f-block metal systems, only the $\left[\mathrm{ScF}_{3}\left(\mathrm{RMe}_{2}\right.\right.$-tacn) $(\mathrm{R}=\mathrm{Me}, \mathrm{Bn})$ were successfully synthesised through $\mathrm{Cl} / \mathrm{F}$ halide exchange reactions. $\left[\mathrm{ScF}_{3}\left(\mathrm{BnMe}_{2}\right.\right.$-tacn $\left.)\right]$ was identified as a promising system for future ${ }^{18} \mathrm{~F}$-radiolabelling, although, in contrast to the Group 13 systems, it could only be obtained from the trichloride analogue under anhydrous conditions using $\left[\mathrm{NMe}_{4}\right] \mathrm{F}$ or $\mathrm{Me}_{3} \mathrm{SnF}$ as the fluoride source. However, the trifluoride complex is very stable in water. ${ }^{13}$

In this work, we present an evaluation of the $3 \mathrm{~d}$ transition metal $\left(\mathrm{Cr}^{3+}, \mathrm{Mn}^{3+}, \mathrm{Fe}^{3+}\right.$ and $\left.\mathrm{Co}^{3+}\right)$ trifluoride complexes for possible PET applications. The distorted octahedral $\mathrm{MF}_{3}$ complexes bearing tridentate $\mathrm{Me}_{3}$-tacn and terpy ligands, are described and their stabilities in water probed by UV-vis spectroscopy. Their properties are discussed in order to identify the best prospects for fluorination for future possible applications in PET. Finally, we demonstrate successful ${ }^{18} \mathrm{~F} /{ }^{19} \mathrm{~F}$ isotopic exchange using $\left[\mathrm{FeF}_{3}\left(\mathrm{BnMe}_{2}\right.\right.$-tacn $\left.)\right]$, and confirm its stability in ethanolic phosphate buffered saline (PBS) or human serum albumin (HSA) over at least $2 \mathrm{~h}$.

In setting out the scope for this study, $\mathrm{Ti}^{3+}$ and $\mathrm{V}^{3+}$ were not considered as the former is very readily oxidised, while the latter is also likely to form V(Iv) in aqueous solution. Previous work has shown that $\left[\mathrm{VOF}_{2}\left(\mathrm{Me}_{3}\right.\right.$-tacn $\left.)\right]$ is readily obtained by adding a few drops of water to a methanol solution of $\left[\mathrm{VF}_{3}\left(\mathrm{Me}_{3}\right.\right.$-tacn $\left.)\right]$ in air. ${ }^{14}$ Nickel was also excluded as no trifluoride complexes are known and Ni(III) is reduced in water. ${ }^{15}$ The ligand substitution kinetics for the majority of second and third row transition metal complexes are expected to be too slow to allow sufficiently fast halide substitution, given the short half-life of the ${ }^{18} \mathrm{~F}$ radionuclide.

The electronic configurations of the $3 \mathrm{~d}$ metal ions influence their reactivity and the kinetic robustness of the complexes formed. Neutral trifluoride complexes of these metals are scarce or unknown, in contrast to the heavier halides. Octahedral d $\mathrm{d}^{3} \mathrm{Cr}$ (III) mono-, di- and tri-fluoride complexes with $\mathrm{N}$-donor ligands have been reported. ${ }^{16}$ In particular, complexes of ammonia and amines have been studied extensively for their absorption and emission properties, contributing to the development of inorganic electronic spectroscopy. ${ }^{17}$ The neutral species $\left[\mathrm{CrF}_{3}(\right.$ bipy $\left.)\left(\mathrm{OH}_{2}\right)\right]{ }^{18} \mathrm{fac}$ - $\left[\mathrm{CrF}_{3}\left(\mathrm{Me}_{3} \text {-tacn }\right)\right]^{19,20}$ and mer- $\left[\mathrm{CrF}_{3} \text { (terpy) }\right]^{20}$ have also been reported and structurally characterised. Complexes with tetradentate $\mathrm{N}$-donor ligands can also be found in the literature. ${ }^{21}$ Neutral complexes of $\mathrm{Mn}(\mathrm{III})$ trifluoride with $\mathrm{N}$-donor ligands are known, with the structures of $\left[\mathrm{MnF}_{3}(\mathrm{bipy})\left(\mathrm{OH}_{2}\right)\right],^{22}\left[\mathrm{MnF}_{3}(\mathrm{phen})\right.$ $\left.\left(\mathrm{OH}_{2}\right)\right],^{23}\left[\mathrm{MnF}_{3}(\text { terpy })\right]^{24}$ and $\left[\left\{\mathrm{MnF}_{2}\left(\mathrm{Me}_{3} \text {-tacn }\right)\right\}_{2}(\mu-\mathrm{F})\right]\left[\mathrm{PF}_{6}\right]^{25}$ reported. The $\mathrm{d}^{4}$ configuration associated with $\mathrm{Mn}$ (III) causes a Jahn-Teller distortion, a feature exploited in the synthesis of molecular magnets. ${ }^{26}$ Iron(III) trifluoride complexes reported in the literature include $m e r-\left[\mathrm{FeF}_{3}\left(\mathrm{NH}_{3}\right)_{3}\right]^{27}$ and $f a c$ - $\left[\mathrm{FeF}_{3}\left(\mathrm{Me}_{3}-\right.\right.$ tacn)]. ${ }^{19}$ While octahedral Co(III) complexes with amine ligands have long been known, ${ }^{28}$ no crystal structures of neutral $\mathrm{Co}(\mathrm{III})$ trifluoride complexes with $\mathrm{N}$-donor or O-donor ligands have been reported. mer- $\left[\mathrm{CoF}_{3}\left(\mathrm{NH}_{3}\right)_{3}\right]$ has been characterised spectroscopically. ${ }^{29}$ The coordination chemistry of transition metal fluoride complexes has been reviewed recently, ${ }^{30}$ including their complexes with neutral ligands. ${ }^{15}$

\section{Experimental}

Synthetic procedures and characterisation details are presented in the ESI $\dagger$

\section{${ }^{18} \mathrm{~F} /{ }^{19} \mathrm{~F}$ isotopic exchange radiolabelling procedure}

In a typical experiment, $\left[\mathrm{FeF}_{3}\left(\mathrm{BnMe}_{2}\right.\right.$-tacn $\left.)\right] \cdot 3.5 \mathrm{H}_{2} \mathrm{O}(1 \mathrm{mg}$, $2.36 \mu \mathrm{mol}, 0.1 \mathrm{mg}, 236 \mathrm{nmol}$ or $0.01 \mathrm{mg}, 24 \mathrm{nmol})$ was dissolved in MeCN $(n=8)(0.75 \mathrm{~mL})$. To this solution was added $0.25 \mathrm{~mL}$ of an aqueous solution containing $\left[{ }^{18} \mathrm{~F}\right] \mathrm{F}^{-}(40-180$ $\mathrm{MBq})$ and the vial was heated to $80{ }^{\circ} \mathrm{C}$ for $10 \mathrm{~min}$. The crude reaction solution was diluted with water $(20 \mathrm{~mL})$ so that approximately $10 \%$ of the solvent composition was organic. A small sample $(\sim 100 \mu \mathrm{L})$ of the diluted crude reaction solution was removed for analysis by analytical HPLC, which confirmed the percentage incorporation of $\left[{ }^{18} \mathrm{~F}\right] \mathrm{F}^{-}$into the metal complex (based upon integration of the radio peaks). Approximately 6\% $\left[{ }^{18} \mathrm{~F}\right] \mathrm{F}^{-}$incorporation was observed when the radiolabelling experiment was performed using $1 \mathrm{mg}$ of the iron complex in $\mathrm{MeCN} / \mathrm{H}_{2} \mathrm{O}(75: 25)$ at room temperature. The product was purified by either a SPE process or by HPLC.

\section{SPE purification protocol}

The diluted reaction mixture was trapped on a HLB cartridge, washed with water $(5 \mathrm{~mL} \times 3)$ to remove the residual $\left[{ }^{18} \mathrm{~F}\right] \mathrm{F}^{-}$ and $\mathrm{MeCN}$ and then the product was eluted from the cartridge with ethanol ( $1 \mathrm{~mL}$ ) into either (i) water to result in a formulated product in 80:20 water : EtOH; (ii) PBS to result in a formulated product in $90: 10 \mathrm{PBS}: \mathrm{EtOH}$ or (iii) HSA to result in a formulated product in 90:10 HSA: EtOH. The formulated 
product was analysed by HPLC at $t=0$ and various time intervals up to $120 \mathrm{~min}$.

Experiments were analysed on an Agilent 1290 HPLC system with an Agilent 1260 DAD UV detector (G4212B) and a Bioscan FC3200 sodium iodide PMT with rate meter. Dionex Chromeleon 6.8 Chromatography data recording software was used to integrate the peak areas.

\section{Analytical HPLC method}

Column: Phenomenex Luna $5 \mu \mathrm{m}$ C18(2) $250 \times 4.6 \mathrm{~mm}$.

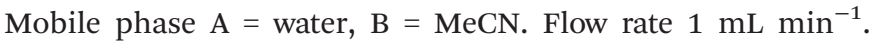
Gradient 0-15 min (10-90\% B), 15-20 min (90\% B), 20-21 min (90-10\% B), 21-26.5 min (10\% B).

\section{HPLC purification}

Column: Waters XBridge Prep Shield RP18, $5 \mu \mathrm{m}, 10 \times 100 \mathrm{~mm}$ (p/n 186003258); Dionex Ultimate 3000 pump; Knauer Smartline 2500 UV detector. Mobile phase A = water; $\mathrm{B}=\mathrm{MeCN}$. Flow rate $3 \mathrm{~mL} \mathrm{~min}^{-1}$. Gradient 0-10 $\mathrm{min}$ (0-10\% B), 10-15 $\mathrm{min}$ (10-90\% B), 15-20 $\min$ (90\% B), 20-25 $\min (90-2 \% \mathrm{~B})$.

\section{Results and discussion}

The syntheses of the complexes $\left[\mathrm{MF}_{3}(\mathrm{~L})\right](\mathrm{M}=\mathrm{Cr}, \mathrm{Mn}, \mathrm{Fe}, \mathrm{Co}$; $\mathrm{L}=$ terpy, $\mathrm{Me}_{3}$-tacn) were carried out in alcoholic ( $n$-BuOH or $\mathrm{MeOH})$ or dmf solutions at room temperature or under reflux (Scheme 1) and the products were characterised by IR spectroscopy, microanalysis and UV-vis spectroscopy (diffuse reflectance and solution).

The trifluoro complexes have a strong tendency to form $\mathrm{H}$-bonding interactions between the fluorides and water molecules in the lattice; ${ }^{8}$ this has often led to discrepancy in the number of water molecules co-crystallised in the lattice compared to the literature ${ }^{19,20,24}$ and in some cases in this work leading to differences in the number of associated water molecules between the bulk materials and the crystal structures (for example $\left[\mathrm{MF}_{3}\left(\mathrm{Me}_{3}\right.\right.$-tacn)], $\mathrm{M}=\mathrm{Mn}$, Co, have two water molecules in the bulk, but four in the crystal structure). This might be due to differences in the crystallisation methods employed and the length of time the bulk materials were dried in vacuo. The products are air stable and can be stored outside the glovebox for several weeks. The stability of the complexes was challenged in aqueous solution by the presence of up to 10 -fold excess of competitive ions ( $\mathrm{NaCl}, \mathrm{NaF}, \mathrm{Na}_{2} \mathrm{CO}_{3}$, $\mathrm{Na}_{3} \mathrm{PO}_{4}, \mathrm{NaOAc}$ ), increased temperature and changes in $\mathrm{pH}$ at two different time points ( $t=0$ and $t=4 \mathrm{~h}$ ). UV-vis spectroscopy was used to monitor the solutions, changes in the position of the relevant $\mathrm{d}-\mathrm{d}$ transitions and or appearance/disappearance of bands were taken as an indication of the instability of the complex during the experiments.

\section{Chromium}

mer-[ $\left[\mathrm{CrF}_{3}(\right.$ terpy $\left.)\right] \cdot 4 \mathrm{H}_{2} \mathrm{O}$ and $f a c-\left[\mathrm{CrF}_{3}\left(\mathrm{Me}_{3}\right.\right.$-tacn $\left.)\right] \cdot 3.5 \mathrm{H}_{2} \mathrm{O}$ were obtained as purple solids in good yields by reaction of $\left[\mathrm{CrF}_{3}(\mathrm{py})_{3}\right]$ with the ligands in $n-\mathrm{BuOH}$ or dmf, respectively, following litera-
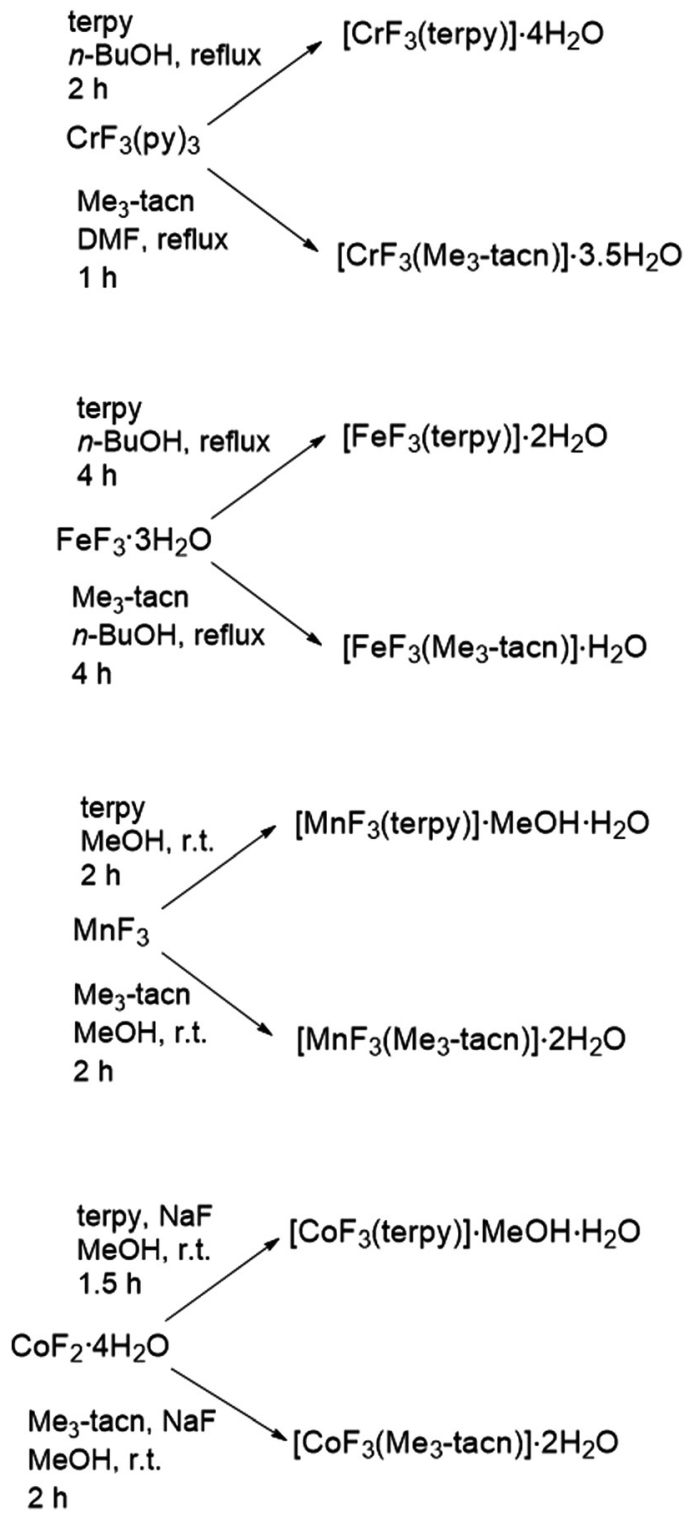

Scheme 1 Reaction conditions for the preparation of the complexes.

ture methods. ${ }^{20}$ The IR spectra of the solids confirm the presence of water and show two $\nu(\mathrm{Cr}-\mathrm{F})$ bands for $\left[\mathrm{CrF}_{3}\left(\mathrm{Me}_{3}\right.\right.$-tacn $\left.)\right] \cdot 3.5 \mathrm{H}_{2} \mathrm{O}$, as expected for a fac octahedral configuration in $C_{3 \mathrm{v}}$ symmetry, whereas one very broad band is seen for $\left[\mathrm{CrF}_{3}(\right.$ terpy) $] \cdot 4 \mathrm{H}_{2} \mathrm{O}$ (three bands are expected in a $m e r C_{2 v}$ symmetry, but not resolved). The diffuse reflectance spectra of the complexes are shown in Fig. S8 and $\mathrm{S} 12, \dagger$ and resemble those reported previously. ${ }^{20}$

\section{Manganese}

The reaction of $\mathrm{MnF}_{3}$ with $\mathrm{Me}_{3}$-tacn or terpy in anhydrous $\mathrm{MeOH}$ at room temperature produces the species $\left[\mathrm{MnF}_{3}\left(\mathrm{Me}_{3}-\right.\right.$ tacn) $] \cdot 2 \mathrm{H}_{2} \mathrm{O}$ and $\left[\mathrm{MnF}_{3}\right.$ (terpy) $] \cdot \mathrm{MeOH} \cdot 3 \mathrm{H}_{2} \mathrm{O}$, respectively. The presence of $\mathrm{MeOH}$ in $\left[\mathrm{MnF}_{3}\right.$ (terpy)] $\cdot \mathrm{MeOH} \cdot 3 \mathrm{H}_{2} \mathrm{O}$ was confirmed by ${ }^{1} \mathrm{H}$ NMR spectroscopy $\left(\mathrm{CD}_{3} \mathrm{CN}, \delta=3.28\left(\mathrm{CH}_{3} \mathrm{OH}\right), 2.15\right.$ $\left.\left(\mathrm{CH}_{3} \mathrm{OH}\right)\right)$. The molecular composition of $\left[\mathrm{MnF}_{3}\left(\mathrm{Me}_{3}\right.\right.$-tacn $\left.)\right]$ was confirmed by a single crystal X-ray structure analysis (Fig. 1). 


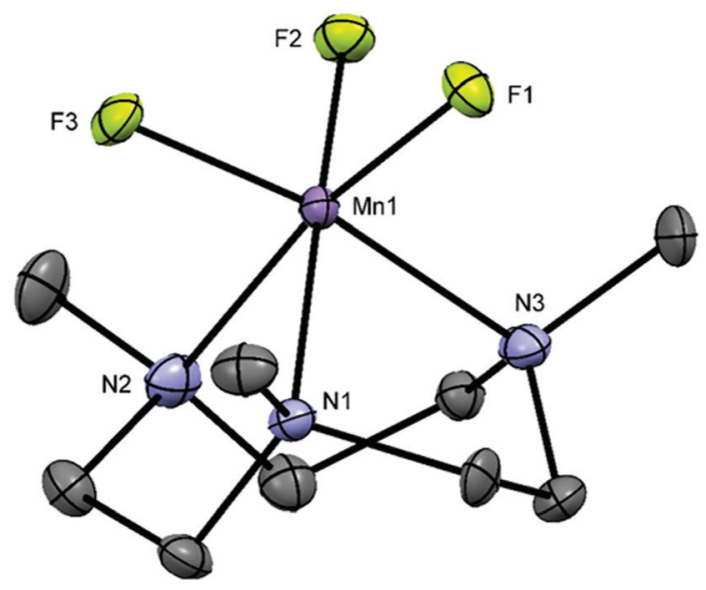

Fig. 1 Crystal structure of fac- $\left[\mathrm{MnF}_{3}\left(\mathrm{Me}_{3}-\mathrm{tacn}\right)\right] \cdot 4 \mathrm{H}_{2} \mathrm{O}$ with ellipsoids drawn at the $50 \%$ probability level. $\mathrm{H}$ atoms and water molecules are omitted for clarity. Select bond lengths $(\AA)$ and angles $\left({ }^{\circ}\right)$ : Mn1-F1 = 2.017(2), Mn1-F2 = 1.852(2), Mn1-F3 = 1.848(2), Mn1-N1 = 2.080(3), $\mathrm{Mn} 1-\mathrm{N} 2=2.267(3), \mathrm{Mn} 1-\mathrm{N} 3=2.096(3), \mathrm{F} 1-\mathrm{Mn} 1-\mathrm{N} 1=91.29(10)$, $\mathrm{F} 3-\mathrm{Mn1}-\mathrm{N} 3=170.31(11), \mathrm{F} 2-\mathrm{Mn} 1-\mathrm{N} 1=172.65(10), \mathrm{F} 1-\mathrm{Mn1}-\mathrm{F} 3=$ 94.88(9), F1-Mn1-F2 = 94.43(9), N1-Mn1-N2 = 80.92(11), N1-Mn1$\mathrm{N} 3=83.43(11)$.

The structure shows a distorted octahedral environment with the fluorides facially coordinated to the metal. The MnF3 and Mn-N3 bond lengths are elongated by $\sim 0.17 \AA$ and $\sim 0.18 \AA$ compared to the other $\mathrm{Mn}-\mathrm{F}$ and $\mathrm{Mn}-\mathrm{N}$ distances, respectively. This significant difference in the bond lengths is consistent with a Jahn-Teller distortion in the high spin $\mathrm{d}^{4}$ configuration. $^{25}$ As confirmation of this, the complex has a magnetic moment of $4.94 \mathrm{BM}^{31}$ The tetragonal elongation in the related complex $\left[\left\{\mathrm{MnF}_{2}\left(\mathrm{Me}_{3}-\mathrm{tacn}\right)\right\}_{2}(\mu-\mathrm{F})\right]\left[\mathrm{PF}_{6}\right]^{25}$ is observed along the axis on which $\mathrm{Mn}-\mathrm{F}_{\text {bridging }}$ and $\mathrm{Mn}-\mathrm{N}$ trans to it lie. These bond lengths are $\sim 0.18$ and $\sim 0.23 \AA$ longer than the other $\mathrm{Mn}-\mathrm{N}$ and $\mathrm{Mn}-\mathrm{F}$ bonds, respectively. ${ }^{25}$ The $\mathrm{Mn}-\mathrm{F}_{\text {terminal }}$ distance in $\left[\left\{\mathrm{MnF}_{2}\left(\mathrm{Me}_{3} \text {-tacn }\right)\right\}_{2}(\mu-\mathrm{F})\right]\left[\mathrm{PF}_{6}\right]$ is $\sim 0.03 \AA$ shorter than Mn1-F1 and Mn1-F2 in $\left[\mathrm{MnF}_{3}\left(\mathrm{Me}_{3}\right.\right.$-tacn) $] \cdot 2 \mathrm{H}_{2} \mathrm{O}$. Extensive H-bonding involving the water molecules and the fluorides is also present (Fig. 2). The same H-bonding pattern was observed in $\left[\mathrm{GaF}_{3}\left(\mathrm{Me}_{3}\right.\right.$-tacn $\left.)\right] \cdot 4 \mathrm{H}_{2} \mathrm{O}{ }^{7}$

The diffuse reflectance UV-vis spectrum of $\left[\mathrm{MnF}_{3}\left(\mathrm{Me}_{3}-\right.\right.$ tacn)] $4 \mathrm{H}_{2} \mathrm{O}$ (Fig. $\mathrm{S} 19 \dagger$ ) shows intense bands in the UV region due to ligand to metal charge transfer transitions $(\sigma \mathrm{N} \rightarrow \mathrm{Mn})$ and a single $\mathrm{d}-\mathrm{d}$ transition at $\sim 520 \mathrm{~nm}$, generically assigned

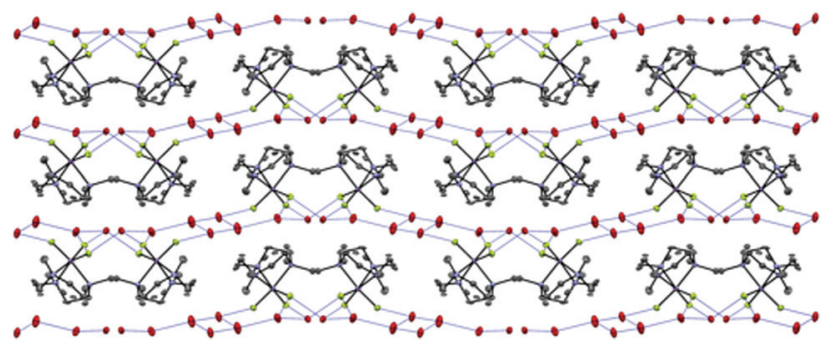

Fig. $2 \mathrm{H}$-Bonding interaction present in $\left[\mathrm{MnF}_{3}\left(\mathrm{Me}_{3}\right.\right.$-tacn)] $4 \mathrm{H}_{2} \mathrm{O}$. to ${ }^{5} \mathrm{E}_{\mathrm{g}} \rightarrow{ }^{5} \mathrm{~T}_{2 \mathrm{~g}}$. Although in an octahedral $\mathrm{d}^{4}$ high spin configuration only one spin-allowed transition is predicted $\left({ }^{5} \mathrm{E}_{\mathrm{g}} \rightarrow{ }^{5} \mathrm{~T}_{2 \mathrm{~g}}\right)$, Jahn-Teller distortions can often lower the symmetry, resulting in splitting of the single transition. However, in this case splitting is not resolved. These data resemble those of the dimer $\left[\left\{\mathrm{MnF}_{2}\left(\mathrm{Me}_{3} \text {-tacn }\right)\right\}_{2}(\mu-\mathrm{F})\right]\left[\mathrm{PF}_{6}\right] .{ }^{25}$

Splitting is more resolved in $\left[\mathrm{MnF}_{3}(\right.$ terpy) $] \cdot \mathrm{MeOH} \cdot 3 \mathrm{H}_{2} \mathrm{O}$ (Fig. $\mathrm{S} 15 \dagger$ ) and the three bands shown in the spectra are tentatively assigned to ${ }^{5} \mathrm{~B}_{1 \mathrm{~g}} \rightarrow{ }^{5} \mathrm{~A}_{1 \mathrm{~g}},{ }^{5} \mathrm{~B}_{1 \mathrm{~g}} \rightarrow{ }^{5} \mathrm{~B}_{2 \mathrm{~g}},{ }^{5} \mathrm{~B}_{1 \mathrm{~g}} \rightarrow{ }^{5} \mathrm{E}_{\mathrm{g}}$. The metal centre symmetry is $C_{2 \mathrm{v}}$ and it is possible that both this and the Jahn-Teller effect results in greater splitting of the bands compared to $\left[\mathrm{MnF}_{3}\left(\mathrm{Me}_{3}\right.\right.$-tacn) $] \cdot 2 \mathrm{H}_{2} \mathrm{O}$. Strong absorptions at high energy, due to the LMCT transitions, $\sigma \mathrm{N} \rightarrow \mathrm{Mn}$, and $\pi-\pi^{*}$ transitions within the aromatic rings, are also present.

\section{Iron}

$\left[\mathrm{FeF}_{3}\left(\mathrm{Me}_{3}\right.\right.$-tacn) $] \cdot \mathrm{H}_{2} \mathrm{O}$ was obtained as a pale yellow solid (in contrast to the green colour reported previously in the literature ${ }^{19}$ ) after reaction of $\mathrm{FeF}_{3} \cdot 3 \mathrm{H}_{2} \mathrm{O}$ with $\mathrm{Me}_{3}$-tacn in refluxing $n$-BuOH. Its IR spectrum shows the expected two $\nu(\mathrm{Fe}-\mathrm{F})$ bands at 512 and $529 \mathrm{~cm}^{-1}$. $\left[\mathrm{FeF}_{3}\right.$ (terpy)] $2 \mathrm{H}_{2} \mathrm{O}$, made using the same method, was obtained as a light purple powder and characterised similarly. The diffuse reflectance UV-vis spectra of the complexes are shown in Fig. S26 and S30. $\uparrow$ The electronic transitions in a $\mathrm{d}^{5}$ high spin system with a ground state ${ }^{6} \mathrm{~A}_{1 \mathrm{~g}}$ are all spin-forbidden and weak bands in the visible region are therefore seen.

Crystals suitable for single crystal X-ray analysis of $\left[\mathrm{FeF}_{3}(\right.$ terpy) $] \cdot 3 \mathrm{H}_{2} \mathrm{O}$ were obtained by slow evaporation of a concentrated solution of the complex in water (Fig. 3).

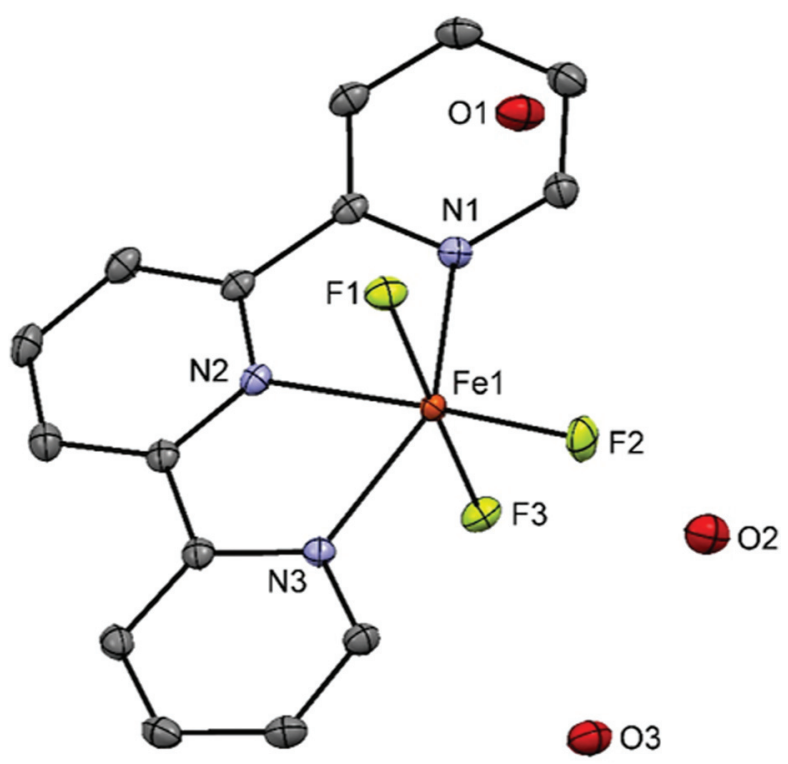

Fig. 3 Crystal structure of $m e r-\left[\mathrm{FeF}_{3}(\right.$ terpy) $] \cdot 3 \mathrm{H}_{2} \mathrm{O}$ with ellipsoids drawn at the $50 \%$ probability level. $\mathrm{H}$ atoms are omitted for clarity. Selected bond lengths $(\AA)$ and angles $\left({ }^{\circ}\right)$ : Fe1-F1 $=1.8774(8), F e 1-F 2=1.8563(8)$, $\mathrm{Fe} 1-\mathrm{F} 3=1.9062(8), \mathrm{Fe} 1-\mathrm{N} 1=2.1564(12), \mathrm{Fe} 1-\mathrm{N} 2=2.1144(12), \mathrm{Fe} 1-$ $\mathrm{N} 3=2.1410(11), \mathrm{F} 1-\mathrm{Fe} 1-\mathrm{N} 1=88.03(4), \mathrm{F} 3-\mathrm{Fe} 1-\mathrm{N} 3=0.89 .78(4), \mathrm{F} 2-$ $\mathrm{Fe} 1-\mathrm{N} 1=110.00(4), \mathrm{F} 1-\mathrm{Fe} 1-\mathrm{F} 3=176.33(4), \mathrm{F} 1-\mathrm{Fe} 1-\mathrm{F} 2=91.20(4), \mathrm{N} 1-$ $\mathrm{Fe} 1-\mathrm{N} 2=74.69(4), \mathrm{N} 1-\mathrm{Fe} 1-\mathrm{N} 3=149.17(4), \mathrm{F} 2-\mathrm{Fe} 1-\mathrm{N} 2=174.92(4)$. 
The structure shows a meridional configuration around the metal. The $\mathrm{Fe}-\mathrm{F}$ bond lengths are slightly longer than those in $\left[\mathrm{FeF}_{3}\left(\mathrm{Me}_{3}-\mathrm{tacn}\right)\right] \cdot \mathrm{H}_{2} \mathrm{O}^{19} \quad(1.878-1.907 \AA$ vs. $1.850-1.866 \AA)$ whereas the opposite trend is seen in the Fe- $\mathrm{N}$ bonds with the terpy complex having the shortest $\mathrm{Fe}-\mathrm{N}$ distance $(2.142-2.156$ vs. 2.223-2.228). The rigidity of the terpy ligand forces some of the angles to deviate from the $180 / 90^{\circ}$ expected for an octahedron. Extensive $\mathrm{H}$-bonding and $\pi$-stacking interactions are also present in the lattice (Fig. S1†).

\section{Cobalt}

$\left[\mathrm{CoF}_{3}\left(\mathrm{Me}_{3}\right.\right.$-tacn) $] \cdot 2 \mathrm{H}_{2} \mathrm{O}$ and $\left[\mathrm{CoF}_{3}(\right.$ terpy $\left.)\right] \cdot \mathrm{MeOH} \cdot \mathrm{H}_{2} \mathrm{O}$ were prepared by oxidising $\mathrm{CoF}_{2} \cdot 4 \mathrm{H}_{2} \mathrm{O}$ to $\mathrm{Co}(\mathrm{III})$ in air in the presence of $\mathrm{NaF}$ and the appropriate ligand. The reactions were carried out in $\mathrm{MeOH}$ at room temperature. The complexes were characterised by UV-vis and IR spectroscopy and by ${ }^{1} \mathrm{H},{ }^{19} \mathrm{~F}\left\{{ }^{1} \mathrm{H}\right\}$ and ${ }^{59} \mathrm{Co}$ NMR spectroscopy, given the diamagnetic $\mathrm{d}^{6}$ low spin electronic configuration of the complexes. The ${ }^{19} \mathrm{~F}\left\{{ }^{1} \mathrm{H}\right\}$ NMR spectra of the complexes in $\mathrm{CD}_{3} \mathrm{OD}$ show broad resonances, with no resolved ${ }^{1} J_{\mathrm{F}-\mathrm{Co}}$ coupling, at $-149\left(\left[\mathrm{CoF}_{3}\left(\mathrm{Me}_{3}-\right.\right.\right.$ tacn $\left.)] \cdot 2 \mathrm{H}_{2} \mathrm{O}\right)$ and $-116 \mathrm{ppm}\left(\left[\mathrm{CoF}_{3}(\right.\right.$ terpy $\left.\left.)\right] \cdot \mathrm{MeOH} \cdot \mathrm{H}_{2} \mathrm{O}\right)$. The ${ }^{59} \mathrm{Co}\left(I=7 / 2, Q=0.42 \times 10^{-28} \mathrm{~m}^{2}\right)^{32}$ NMR spectra show very broad peaks at $\sim 9000$ and $8600 \mathrm{ppm}$ respectively, which are in the range of other octahedral $\mathrm{Co}$ (III) complexes, such as [Co $\left.\left(\mathrm{NH}_{3}\right)_{6}\right]^{3+}$ and $\left[\mathrm{Co}(\mathrm{en})_{3}\right]^{3+} .^{33}$ However, when the spectrum of $\left[\mathrm{CoF}_{3}\left(\mathrm{Me}_{3}\right.\right.$-tacn $\left.)\right] \cdot 2 \mathrm{H}_{2} \mathrm{O}$ is recorded in $\mathrm{D}_{2} \mathrm{O}$ solution, the ${ }^{19} \mathrm{~F}\left\{{ }^{1} \mathrm{H}\right\}$ NMR resonance associated with the complex is lost and only $\mathrm{F}^{-}$is present (118.9 ppm).

The UV-vis diffuse reflectance spectra of the complexes are shown in Fig. S34 and S40.† The two spin-allowed transitions predicted for a low spin $\mathrm{d}^{6}$ system are present in the spectrum of $f a c$ - $\left[\mathrm{CoF}_{3}\left(\mathrm{Me}_{3}\right.\right.$-tacn)] (Fig. S40 $\dagger$ ) at $\sim 570$ and $\sim 375 \mathrm{~nm}$ and are assigned to ${ }^{1} \mathrm{~A}_{1 \mathrm{~g}} \rightarrow{ }^{1} \mathrm{~T}_{1 \mathrm{~g}}$ and ${ }^{1} \mathrm{~A}_{1 \mathrm{~g}} \rightarrow{ }^{1} \mathrm{~T}_{2 \mathrm{~g}}$, respectively. The $m e r-\left[\mathrm{CoF}_{3}\right.$ (terpy)] $\mathrm{MeOH} \cdot \mathrm{H}_{2} \mathrm{O}$ has $C_{2 \mathrm{v}}$ symmetry and splitting is greater than in the $\mathrm{Me}_{3}$-tacn complex $\left(C_{3 \mathrm{v}}\right)$. The ${ }^{1} \mathrm{~T}_{1 \mathrm{~g}}$ level split into three components and the transitions observed are tentatively assigned to ${ }^{1} \mathrm{~A}_{1 g} \rightarrow{ }^{1} \mathrm{~B}_{1 g},{ }^{1} \mathrm{~A}_{1 g} \rightarrow{ }^{1} \mathrm{~B}_{2 g}$ and ${ }^{1} \mathrm{~A}_{1 \mathrm{~g}} \rightarrow{ }^{1} \mathrm{~B}_{3 g}$ (Fig. S34, $\dagger$ from low to high energy). ${ }^{17,34}$ In this case, the third (higher energy) spin-allowed transition ${ }^{1} \mathrm{~A}_{1 g} \rightarrow{ }^{1} \mathrm{~T}_{2 g}$ is masked by the ligand to metal charge transfer and/or $\pi-\pi^{*}$ bands involving the terpy ligand. Crystals of $\left[\mathrm{CoF}_{3}\left(\mathrm{Me}_{3}\right.\right.$-tacn) $] \cdot 4 \mathrm{H}_{2} \mathrm{O}$ suitable for single crystal X-ray analysis were obtained by slow evaporation of a concentrated solution of the complex in water (Fig. 4). The complex is isostructural to $\left[\mathrm{MnF}_{3}\left(\mathrm{Me}_{3}\right.\right.$-tacn)] $\cdot 4 \mathrm{H}_{2} \mathrm{O}$ and shows the same H-bonding pattern in the lattice (Fig. S2 †).

\section{Stability tests}

The stability of a $10^{-3} \mathrm{M}$ solution of the complexes $\left[\mathrm{MF}_{3}\left(\mathrm{Me}_{3}\right.\right.$ tacn)] $(\mathrm{M}=\mathrm{Cr}, \mathrm{Mn}, \mathrm{Fe})$ and $\left[\mathrm{M}^{\prime} \mathrm{F}_{3}\right.$ (terpy) $](\mathrm{M}=\mathrm{Cr}, \mathrm{Fe})$ was challenged in the presence of up to a 10-fold excess of competitive ions $\left(\mathrm{F}^{-}, \mathrm{Cl}^{-} \mathrm{CO}_{3}{ }^{2-}, \mathrm{PO}_{4}{ }^{3-}, \mathrm{AcO}^{-}\right.$, added as sodium salts), $\mathrm{pH}$ variations (4-11), temperature $\left(80^{\circ} \mathrm{C}\right.$ for $\left.2 \mathrm{~h}\right)$ and time. The spectra acquired were compared with the spectra of the relevant reference complex. Given the limited stability of

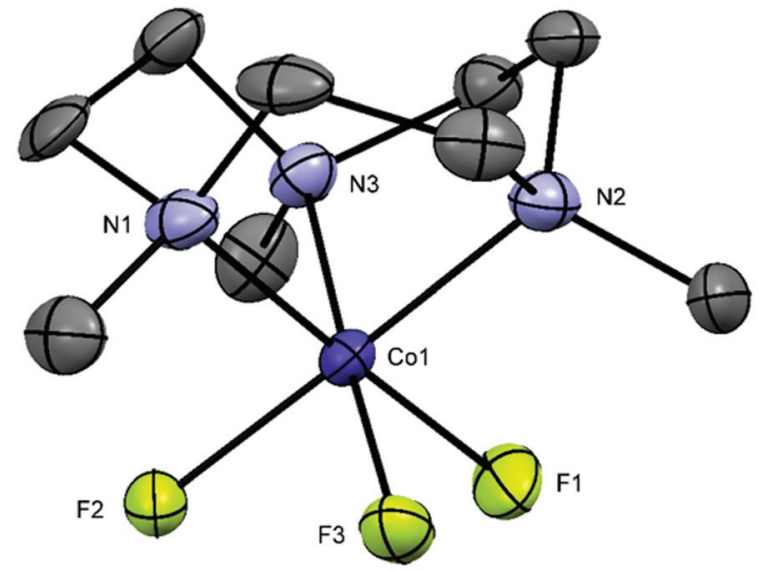

Fig. 4 Crystal structure of fac- $\left[\mathrm{CoF}_{3}\left(\mathrm{Me}_{3}\right.\right.$-tacn) $] \cdot 4 \mathrm{H}_{2} \mathrm{O}$ with ellipsoids drawn at the $50 \%$ probability level. $\mathrm{H}$ atoms and water molecules are omitted for clarity. Selected bond lengths $(\AA \AA)$ and angles $\left({ }^{\circ}\right)$ : Co1-F1 = 1.857(3), Co1-F2 = 1.871(2), Co1-F3 = 1.871(3), Co1-N1 = 1.960(4), Co1-N2 = 1.960(4), Co1-N3 = 1.958(4), F1-Co1-N1 = 178.30(14), F3Co1-N3 = 178.13(14), F2-Co1-N1 = 91.39(14), F1-Co1-F3 = 88.29(13), $\mathrm{F} 1-\mathrm{Co} 1-\mathrm{F} 2=89.92(12), \mathrm{N} 1-\mathrm{Co} 1-\mathrm{N} 2=87.62(16), \mathrm{N} 1-\mathrm{Co} 1-\mathrm{N} 3=$ 87.95(15).

$\left[\mathrm{CoF}_{3}\left(\mathrm{Me}_{3}\right.\right.$-tacn $\left.)\right] \cdot 2 \mathrm{H}_{2} \mathrm{O}$ in water, stability tests were not carried out on this complex.

$\left[\mathrm{CrF}_{3}\left(\mathrm{Me}_{3}\right.\right.$-tacn $\left.)\right] \cdot 3.5 \mathrm{H}_{2} \mathrm{O}$ appears to be stable under all conditions tested (Fig. 5), whereas $\left[\mathrm{CrF}_{3}\right.$ (terpy) $] \cdot 4 \mathrm{H}_{2} \mathrm{O}$ is not stable in the presence of $\mathrm{PO}_{4}{ }^{3-}$ after $4 \mathrm{~h}$ (the $558 \mathrm{~nm}$ band shifts to lower energy by $\sim 10 \mathrm{~nm}$ ). Both complexes are unaffected by heating at $80{ }^{\circ} \mathrm{C}$ for $2 \mathrm{~h}$ and after standing for an extended period (one week) in aqueous solution (Fig. S11† and Fig. 5).

The stability of the Mn(III) complex is inferior to that of the $\mathrm{Cr}(\mathrm{III})$ analogue, as expected for a d $\mathrm{d}^{4}$ system. $\left[\mathrm{MnF}_{3}\left(\mathrm{Me}_{3}-\right.\right.$ tacn)] $2 \mathrm{H}_{2} \mathrm{O}$ (Fig. S23 $\dagger$ ) is stable to the presence of excess chloride and fluoride, but is unstable to phosphate, acetate and carbonate even at $t=0$, with no significant further change observed after $4 \mathrm{~h}$. Moreover, $\mathrm{pH}>4$ also results in the decomposition of the complex, as also observed upon heating and prolonged exposure in aqueous solution. Decomposition of the sample was clearly observable as a black solid formed, most likely $\mathrm{MnO}_{2}$ or $\mathrm{MnO}(\mathrm{OH})$. Considering the already problematic stability of $\left[\mathrm{MnF}_{3}\left(\mathrm{Me}_{3}\right.\right.$-tacn)] $2 \mathrm{H}_{2} \mathrm{O}$, the stability tests on $\left[\mathrm{MnF}_{3}(\right.$ terpy $\left.)\right] \cdot \mathrm{MeOH} \cdot 3 \mathrm{H}_{2} \mathrm{O}$ were not pursued.

The results of the stability tests on $\left[\mathrm{FeF}_{3}\left(\mathrm{Me}_{3}\right.\right.$-tacn) $] \cdot \mathrm{H}_{2} \mathrm{O}$ are shown in Fig. S33. $\uparrow$ The complex is stable to the presence of all the anions studied at $t=0$. However, the spectra acquired after $4 \mathrm{~h}$ show that the presence of carbonate anions causes decomposition of the complex. Similar behaviour was observed in the $\mathrm{pH} 7$ experiment (stable at $t=0$ and unstable at $t=4 \mathrm{~h}$ ), whereas the complex is unstable at $\mathrm{pH} 11$ from $t=$ 0 . The complex is stable after $2 \mathrm{~h}$ at $80{ }^{\circ} \mathrm{C}$ in water and is unchanged after one week in aqueous solution. The stability tests on $\left[\mathrm{FeF}_{3}\right.$ (terpy) $] \cdot 2 \mathrm{H}_{2} \mathrm{O}$ in the same conditions (Fig. S29 $\dagger$ ) showed that the positions of the peaks were unchanged, however a change in their intensity and in the colour of the 

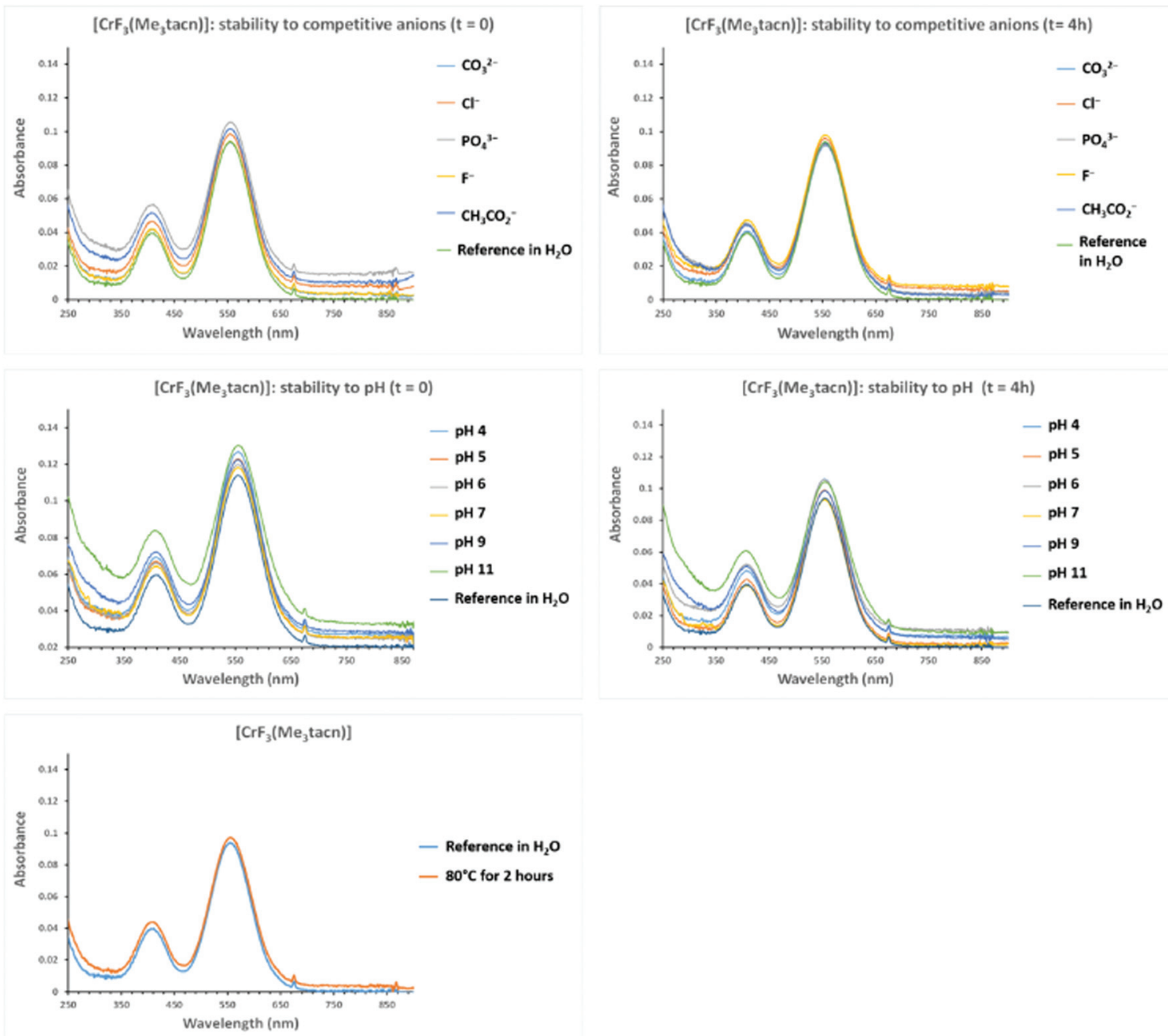

Fig. 5 Stability test of $\left[\mathrm{CrF}_{3}\left(\mathrm{Me}_{3}\right.\right.$-tacn)]-3.5 $\mathrm{H}_{2} \mathrm{O}$. First row from the top: UV-vis spectra of the complex in the presence of a 10-fold excess anions at (left) $t=0$ and (right) $t=4$ hours; middle row: UV-vis spectra of the complex at different pH conditions at (left) $t=0$ and (right) $t=4$ hours; bottom row: UV-vis spectra of the complex after two hours at $80^{\circ} \mathrm{C}$.

solution of the complex in water from red to pink was observed.

\section{Halide exchange reactions on $\left[\mathrm{MCl}_{3}\left(\mathrm{Me}_{3}\right.\right.$-tacn $\left.)\right](\mathrm{M}=\mathrm{Cr}, \mathrm{Fe})$}

Since radioactive $\left[{ }^{18} \mathrm{~F}^{-} \mathrm{F}^{-}\right.$can be incorporated into $\left[\mathrm{AlCl}_{3}\left(\mathrm{BnMe}_{2}\right.\right.$-tacn $\left.)\right], \quad\left[\mathrm{GaCl}_{3}\left(\mathrm{BnMe}_{2}\right.\right.$-tacn $\left.)\right]$ and $[\mathrm{GaCl}(\mathrm{Bn}$ $\left(\mathrm{CH}_{2} \mathrm{COO}\right)_{2}$-tacn $\left.)\right]$ through $\mathrm{Cl}^{-} / \mathrm{F}^{-}$exchange reactions, ${ }^{6,8}$ this possibility was explored for $\left[\mathrm{MCl}_{3}\left(\mathrm{Me}_{3}\right.\right.$-tacn $\left.)\right](\mathrm{M}=\mathrm{Cr}, \mathrm{Fe})$ through preliminary experiments using non-radioactive $\left[\mathrm{NMe}_{4}\right]^{19} \mathrm{~F}$ or $\mathrm{K}^{19} \mathrm{~F}$ as test reactions on a preparative scale. Given the instability of $\left[\mathrm{MnF}_{3}\left(\mathrm{Me}_{3}\right.\right.$-tacn) $]$ in the majority of the conditions tested and the limited stability of $\left[\mathrm{CoF}_{3}\left(\mathrm{Me}_{3}-\right.\right.$ tacn)] $2 \mathrm{H}_{2} \mathrm{O}$ in water, fluorination reactions to form these complexes were not pursued.

The $\mathrm{Cl} / \mathrm{F}$ substitution on $\left[\mathrm{CrCl}_{3}\left(\mathrm{Me}_{3}\right.\right.$-tacn $\left.)\right]$ was incomplete after $24 \mathrm{~h}$ under reflux in $\mathrm{MeCN}$ in the presence of $4 \mathrm{~mol}$. equiv. of $\left[\mathrm{NMe}_{4}\right] \mathrm{F}$. The crude solid obtained was analysed by IR spectroscopy and compared with the IR spectra of $\left[\mathrm{CrCl}_{3}\left(\mathrm{Me}_{3}-\right.\right.$ tacn) $]$ and $\left[\mathrm{CrF}_{3}\left(\mathrm{Me}_{3}\right.\right.$-tacn) $]$ (Fig. S3 $\dagger$ ), showing that the $\mathrm{CrF}_{3}$ - complex is formed during the reaction ( $\left.\nu \mathrm{Cr}-\mathrm{F} 539,507 \mathrm{~cm}^{-1}\right)$ but it appears that some $\mathrm{CrCl}_{3}$-complex and/or mixed chloride/ fluoride species are still present $\left(\nu \mathrm{Cr}-\mathrm{Cl} 343,333 \mathrm{~cm}^{-1}\right)$. This is not surprising given the slow substitution kinetics in the $\mathrm{d}^{3}$ systems. However, much more promisingly, $\left[\mathrm{FeCl}_{3}\left(\mathrm{Me}_{3}\right.\right.$-tacn)] was successfully fluorinated in the presence of either 4 mol. equiv. of $\left[\mathrm{NMe}_{4}\right] \mathrm{F}$ in anhydrous MeCN under reflux for $4 \mathrm{~h}$ or using $4 \mathrm{~mol}$. equiv. of $\mathrm{KF}$ in aqueous $\mathrm{MeCN}$ at room temperature within $30 \mathrm{~min}$. $\left[\mathrm{FeF}_{3}\left(\mathrm{Me}_{3}\right.\right.$-tacn) $]$ was isolated after work-up and characterised by IR spectroscopy. Comparison of the IR spectra of the parent $\left[\mathrm{FeCl}_{3}\left(\mathrm{Me}_{3}\right.\right.$-tacn) $]$ and $\left[\mathrm{FeF}_{3}\left(\mathrm{Me}_{3}\right.\right.$-tacn $\left.)\right]$ with the product obtained from the halide exchange reaction is shown in Fig. 6.

It can be seen that the IR spectrum of $\left[\mathrm{FeF}_{3}\left(\mathrm{Me}_{3}\right.\right.$-tacn)] (Fig. 6, red line) obtained by the halide exchange reaction in aqueous MeCN shows the disappearance of the $\mathrm{Fe}-\mathrm{Cl}$ stretches ( $\sim 300$ and $\sim 310 \mathrm{~cm}^{-1}$, blue line) and the peaks at $\sim 510$ and $\sim 525 \mathrm{~cm}^{-1}$ match the Fe-F stretches in the spectrum of the reference compound, $\left[\mathrm{FeF}_{3}\left(\mathrm{Me}_{3}\right.\right.$-tacn) $]$ (black line), obtained directly from the reaction of $\mathrm{FeF}_{3} \cdot 3 \mathrm{H}_{2} \mathrm{O}$ and $\mathrm{Me}_{3}$-tacn. 


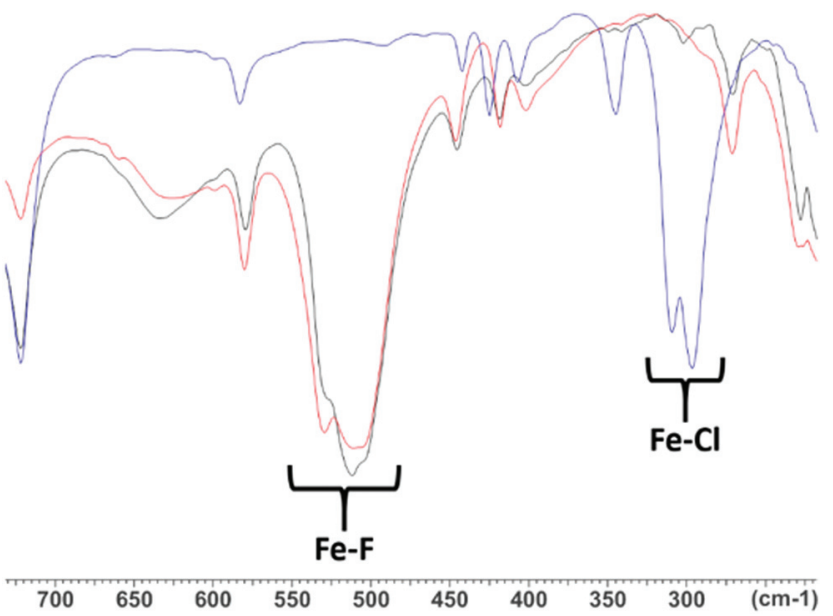

Fig. 6 Comparison of the IR spectra of $\left[\mathrm{FeCl}_{3}\left(\mathrm{Me}_{3}\right.\right.$-tacn)] (blue), $\left[\mathrm{FeF}_{3}\left(\mathrm{Me}_{3}\right.\right.$-tacn)] (black) and $\left(\mathrm{FeF}_{3}\left(\mathrm{Me}_{3}\right.\right.$-tacn)) from the halide exchange reaction (red).

These studies suggest that the $\left[\mathrm{FeF}_{3}\left(\mathrm{R}_{3}\right.\right.$-tacn $\left.)\right]$ system may be worth further investigation as a possible platform for PET applications. In order to test this, the Bn-substituted analogue, $\left[\mathrm{FeF}_{3}\left(\mathrm{BnMe}_{2}\right.\right.$-tacn) $]$ was prepared; the presence of the Bn group aids identification of the final radio-product via UV-vis spectroscopy. The crystal structure (Fig. 7) confirms the formulation $\left[\mathrm{FeF}_{3}\left(\mathrm{BnMe}_{2}\right.\right.$-tacn $\left.)\right] \cdot 2 \mathrm{H}_{2} \mathrm{O}$, with two co-crystallised water molecules in the lattice. Two crystallographically independent molecules are present in the asymmetric unit, although the bond distances are not significantly different.

\section{Radiofluorination}

${ }^{18} \mathrm{~F}$-radiofluorination of $\left[\mathrm{FeF}_{3}\left(\mathrm{BnMe}_{2}\right.\right.$-tacn $\left.)\right]$ was achieved through ${ }^{18} \mathrm{~F} /{ }^{19} \mathrm{~F}$ isotopic exchange reactions in unbuffered $75: 25 \mathrm{MeCN}: \mathrm{H}_{2} \mathrm{O}$ and heating the mixture to $80{ }^{\circ} \mathrm{C}$ for

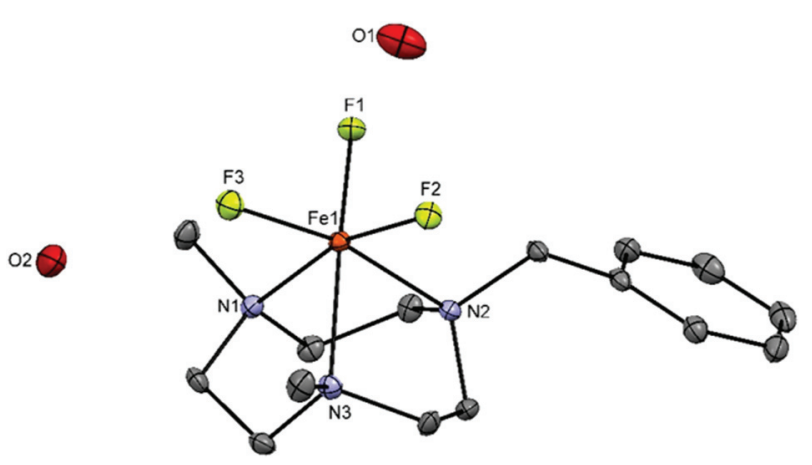

Fig. 7 Crystal structure of $\left[\mathrm{FeF}_{3}\left(\mathrm{BnMe}_{2}-\mathrm{tacn}\right) \cdot 2 \mathrm{H}_{2} \mathrm{O}\right.$ showing the atom numbering scheme and with ellipsoids drawn at the $50 \%$ probability level. $\mathrm{H}$ atoms are omitted for clarity. Selected bond lengths (Å) and angles $\left({ }^{\circ}\right)$ : Fe1-F1 $=1.8878(19), F e 1-F 2=1.8673(17), F e 1-F 3=1.8778$ (19), Fe1-N1 = 2.206(2), Fe1-N2 = 2.237(3), Fe1-N3 = 2.197(3), F1-Fe1$\mathrm{F} 2=99.00(8), \mathrm{F} 1-\mathrm{Fe} 1-\mathrm{F} 3=95.91(8), \mathrm{F} 2-\mathrm{Fe} 1-\mathrm{F} 3=99.13(8), \mathrm{F} 1-\mathrm{Fe} 1-\mathrm{N} 3$ $=167.58(9), \mathrm{F} 1-\mathrm{Fe} 1-\mathrm{N} 2=90.30(9), \mathrm{F} 1-\mathrm{Fe} 1-\mathrm{N} 1=91.36(9), \mathrm{F} 3-\mathrm{Fe} 1-\mathrm{N} 2$ $=167.08(9), \mathrm{F} 2-\mathrm{Fe} 1-\mathrm{N} 1=165.67(8), \mathrm{N} 1-\mathrm{Fe} 1-\mathrm{N} 2$ = 78.96(9), N1-Fe1N3 $=79.32(9), \mathrm{N} 2-\mathrm{Fe} 1-\mathrm{N} 3=79.92(10)$.

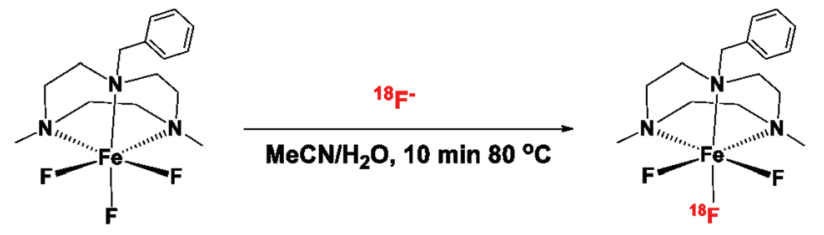

Scheme $2{ }^{18} \mathrm{~F}$ radiolabelling conditions.

$10 \mathrm{~min}$ (Scheme 2). The water used in the reaction is the target water containing $\left[{ }^{18} \mathrm{~F}\right] \mathrm{F}^{-}$directly received from the cyclotron, without further purification. The reaction produces $\left[\mathrm{Fe}^{18} \mathrm{~F}^{19} \mathrm{~F}_{2}\left(\mathrm{BnMe}_{2}\right.\right.$-tacn)] in a $\sim 40 \%$ radiochemical yield (RCY) when starting with 1 and $0.1 \mathrm{mg}$ (2360 and $236 \mathrm{nmol}$ respectively) of $\left[\mathrm{Fe}^{19} \mathrm{~F}_{3}\left(\mathrm{BnMe}_{2}\right.\right.$-tacn)], along with unreacted $\left[{ }^{18} \mathrm{~F}\right] \mathrm{F}^{-}$. The identity of the radio-product was confirmed by comparison with the UV trace of the inactive reference standard. $\left[\mathrm{Fe}^{19} \mathrm{~F}_{3}\left(\mathrm{BnMe}_{2}\right.\right.$-tacn)]. $\left.{ }^{18} \mathrm{~F}\right] \mathrm{F}^{-}$incorporation also occurs within $10 \mathrm{~min}$ at room temperature, although (unsurprisingly) this leads to a considerably lower RCY $(6 \pm 1 \%)$ (Table 1 and

Table $1{ }^{18} \mathrm{~F} /{ }^{19} \mathrm{~F}$ radiolabelling conditions. Reactions performed in $75: 25 \mathrm{MeCN} /$ target water. All experiments were performed at least 2 times

\begin{tabular}{llll}
\hline $\begin{array}{l}{\left[\mathrm{FeF}_{3}\left(\mathrm{BnMe}{ }_{2} \text {-tacn }\right)\right]} \\
(\mathrm{mass} / \mathrm{mg})\end{array}$ & $\begin{array}{l}\text { Scale } \\
(\mathrm{nmol})\end{array}$ & $\begin{array}{l}T /{ }^{\circ} \mathrm{C} \\
(\mathrm{time} / \mathrm{min})\end{array}$ & $\begin{array}{l}\mathrm{RCY} \\
(\%)\end{array}$ \\
\hline 1 & 2360 & $25(10)$ & $6 \pm 1$ \\
1 & 2360 & $80(10)$ & $44 \pm 6$ \\
0.1 & 236 & $80(10)$ & $40 \pm 6$ \\
0.01 & 24 & $80(10)$ & $13 \pm 5$
\end{tabular}

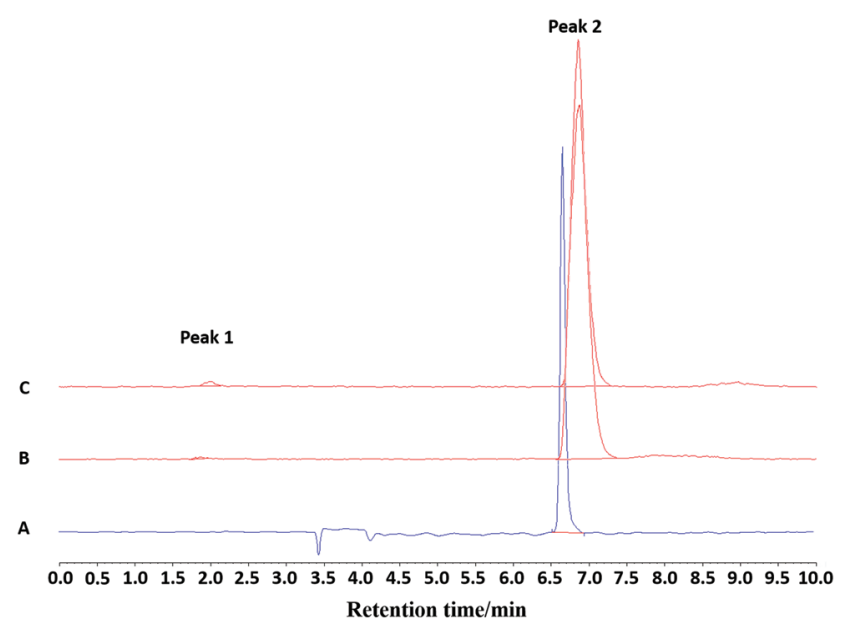

Fig. 8 (A) Analytical UV-HPLC chromatogram of the reference standard compound $\left[\mathrm{Fe}^{19} \mathrm{~F}_{3}\left(\mathrm{BnMe}_{2}\right.\right.$-tacn) $]\left(R_{\mathrm{t}}=6.67 \mathrm{~min}\right)$; $(\mathrm{B})$ analytical radioHPLC chromatogram of the purified product eluted from a HLB cartridge and formulated in $20: 80 \mathrm{EtOH}:$ water at $\mathrm{t}=0$. Peak $2: R_{\mathrm{t}}=$ $6.88 \mathrm{~min}>99 \%\left(\left[\mathrm{Fe}^{18} \mathrm{~F}^{19} \mathrm{~F}_{2}\left(\mathrm{BnMe}_{2}\right.\right.\right.$-tacn) $\left.]\right) ;(\mathrm{C})$ analytical radio-HPLC chromatogram of the purified product eluted from a HLB cartridge and formulated in $20: 80 \mathrm{EtOH}:$ water at $\mathrm{t}=120 \mathrm{~min}$. Peak 1: $R_{\mathrm{t}}=1.99 \mathrm{~min}$ $1 \%\left(\left[{ }^{18} \mathrm{~F}\right] \mathrm{F}^{-}\right)$. Peak 2: $R_{\mathrm{t}}=6.85 \mathrm{~min} 99 \%\left(\left[\mathrm{Fe}^{18} \mathrm{~F}^{19} \mathrm{~F}_{2}\left(\mathrm{BnMe}_{2}-\mathrm{tacn}\right)\right]\right)$. 


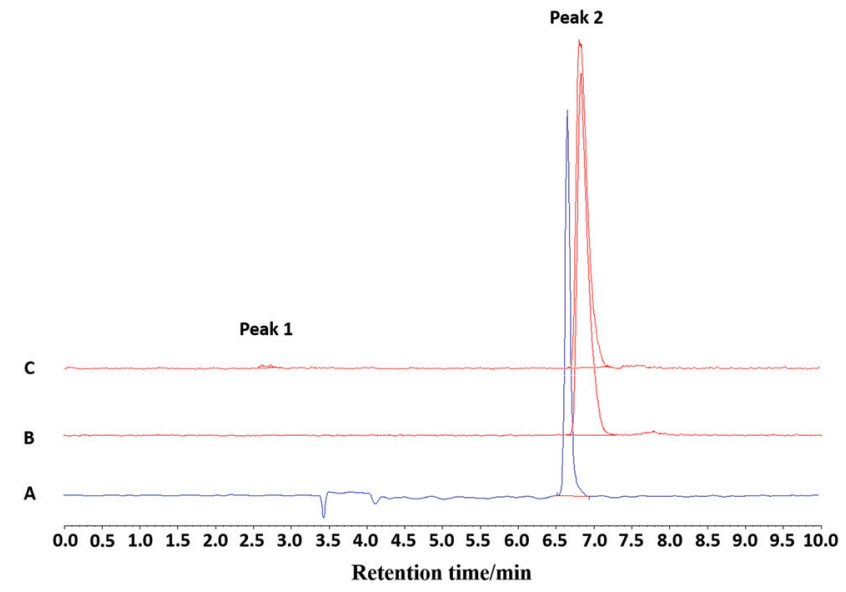

Fig. 9 (A) Analytical UV-HPLC chromatogram of the reference standard compound $\left[\mathrm{Fe}^{19} \mathrm{~F}_{3}\left(\mathrm{BnMe} \mathrm{e}_{2}\right.\right.$-tacn) $]\left(R_{\mathrm{t}}=6.67 \mathrm{~min}\right)$; $(\mathrm{B})$ analytical radioHPLC chromatogram of the purified product eluted from a HLB cartridge and formulated in $10: 90 \mathrm{EtOH}: \mathrm{PBS}$ at $t=0$. Peak 2: $R_{\mathrm{t}}=$ $6.88 \mathrm{~min}>99 \%\left(\left[\mathrm{Fe}^{18} \mathrm{~F}^{19} \mathrm{~F}_{2}\left(\mathrm{BnMe}_{2}\right.\right.\right.$-tacn) $\left.]\right) ;(\mathrm{C})$ analytical radio-HPLC chromatogram of the purified product eluted from a HLB cartridge and formulated in $10: 90 \mathrm{EtOH}$ : PBS at $t=120 \mathrm{~min}$. Peak $1: R_{\mathrm{t}}=2.73 \mathrm{~min} 1 \%$ $\left(\left[{ }^{18} \mathrm{~F}\right] \mathrm{F}^{-}\right)$. Peak 2: $R_{\mathrm{t}}=6.82 \min 99 \%\left(\left[\mathrm{Fe}^{18} \mathrm{~F}^{19} \mathrm{~F}_{2}\left(\mathrm{BnMe}_{2}\right.\right.\right.$-tacn) $)$.

Fig. S52 in ESI $\dagger$ ). Radiofluorination was also achieved using $0.01 \mathrm{mg}$ ( $24 \mathrm{nmol})$ of precursor $\left(80^{\circ} \mathrm{C}\right.$ per $\left.10 \mathrm{~min}\right)$, resulting in $13 \pm 5 \%$ RCY.

The $\left[\mathrm{Fe}^{18} \mathrm{~F}^{19} \mathrm{~F}_{2}\left(\mathrm{BnMe}_{2}\right.\right.$-tacn) $]$ was purified using a solid phase extraction (SPE) protocol through an HLB cartridge to leave the ${ }^{18} \mathrm{~F}$-fluorinated metal-chelate as the single product. The stability of $\left[\mathrm{Fe}^{18} \mathrm{~F}^{19} \mathrm{~F}_{2}\left(\mathrm{BnMe}_{2}\right.\right.$-tacn $\left.)\right]$ was investigated in different formulation solutions (20:80 EtOH:water, 10:90 EtOH : PBS and 10:90 EtOH:HSA, Fig. 8 and 9, Fig. S53 and S54†), showing good stability over at least 2 hours with RCP = 99\% for the EtOH $/ \mathrm{H}_{2} \mathrm{O}$ and $\mathrm{EtOH} / \mathrm{PBS}$, and $\mathrm{RCP}=90 \%$ for EtOH/HSA. The target radioproduct could also be purified through a prep. HPLC system, giving the same RCP at $t=0$ as in the SPE purification protocol.

\section{Conclusions}

Evaluation of the stability of complexes of the type $\left[\mathrm{MF}_{3}(\mathrm{~L})\right]$, where $\mathrm{M}=\mathrm{Cr}(\mathrm{III}), \mathrm{Mn}$ (III), $\mathrm{Fe}(\mathrm{III}), \mathrm{Co}(\mathrm{III})$ and $\mathrm{L}=$ terpy, $\mathrm{Me}_{3}$-tacn, has been carried out by means of UV-vis spectroscopy. The compounds, including the new $\left[\mathrm{MnF}_{3}\left(\mathrm{Me}_{3}\right.\right.$-tacn $\left.)\right]$, $\left[\mathrm{FeF}_{3}(\right.$ terpy)$],\left[\mathrm{FeF}_{3}\left(\mathrm{BnMe}_{2}\right.\right.$-tacn $\left.)\right],\left[\mathrm{CoF}_{3}(\mathrm{~L})\right]$ and $\left[\mathrm{CoCl}_{3}\left(\mathrm{Me}_{3}-\right.\right.$ tacn)], have been synthesised and fully characterised. $\left[\mathrm{CoF}_{3}\left(\mathrm{Me}_{3}\right.\right.$-tacn $\left.)\right]$ represents the first structurally characterised $\mathrm{Co}(\mathrm{III})$ fluoride complex with a neutral $\mathrm{N}$-donor ligand.

The possibility of obtaining the fluoride complexes from the chloride analogues by $\mathrm{Cl} / \mathrm{F}$ exchange reactions on $\left[\mathrm{MF}_{3}\left(\mathrm{Me}_{3}\right.\right.$-tacn $\left.)\right](\mathrm{M}=\mathrm{Cr}, \mathrm{Fe})$ was also explored. Although the bond dissociation energies of the $\mathrm{M}-\mathrm{F}$ bonds are greater than the $\mathrm{M}-\mathrm{Cl}$ bonds in all cases, the combination of thermo- dynamic and kinetic stability greatly affects the complexes and the outcome of the halide exchange reactions.

Stability tests performed on $\left[\mathrm{MF}_{3}\left(\mathrm{Me}_{3}\right.\right.$-tacn) $]$ and $\left[\mathrm{MF}_{3}\right.$ (terpy) $](\mathrm{M}=\mathrm{Cr}, \mathrm{Fe})$ have shown that the terpy complexes do not have the stability required to be a contender for future PET applications. This was also observed in the Group 13 (Al, $\mathrm{Ga}$ ) and $\mathrm{ScF}_{3}$ terpy complexes. ${ }^{8,13}$ Among the complexes with $\mathrm{Me}_{3}$-tacn as ligand, $\left[\mathrm{FeF}_{3}\left(\mathrm{Me}_{3}\right.\right.$-tacn $\left.)\right]$ and $\left[\mathrm{CrF}_{3}\left(\mathrm{Me}_{3}\right.\right.$-tacn $\left.)\right]$ showed good stability in most conditions; however, the reaction kinetics of the $\mathrm{Cl} / \mathrm{F}$ exchange on $\left[\mathrm{CrCl}_{3}\left(\mathrm{Me}_{3}\right.\right.$-tacn) $]$ using 4 mol. equiv. of $\left[\mathrm{Me}_{4} \mathrm{~N}\right] \mathrm{F}$ in $\mathrm{MeCN}$ under reflux proved to be slow, with a mixture of the chloride and fluoride complexes present after $24 \mathrm{~h}$. The $\mathrm{d}^{5}$ system, $\left[\mathrm{FeF}_{3}\left(\mathrm{Me}_{3}\right.\right.$-tacn)], proved to be more successful. Fluorination was achieved within $30 \mathrm{~min}$ in aqueous $\mathrm{MeCN}$ at room temperature using $\mathrm{KF}$ as the fluoride source, causing complete conversion to $\left[\mathrm{FeF}_{3}\left(\mathrm{Me}_{3}\right.\right.$-tacn)].

Stability tests indicated that tacn derivatives bearing the $\mathrm{FeF}_{3}$ fragment may be suitable for radiofluorination, and this was borne out by ${ }^{18} \mathrm{~F} /{ }^{19} \mathrm{~F}$ isotopic exchange reactions using $\left[\mathrm{FeF}_{3}\left(\mathrm{BnMe}_{2}\right.\right.$-tacn) $]$ at concentrations down to $24 \mathrm{nM}$. The resulting $\left[\mathrm{Fe}^{18} \mathrm{~F}^{19} \mathrm{~F}_{2}\left(\mathrm{BnMe}_{2}\right.\right.$-tacn $\left.)\right]$ is stable in ethanolic PBS or HAS over at least $2 \mathrm{~h}$. This constitutes the first example of a transition metal complex where radiofluorination is achieved through formation of a direct $\mathrm{M}-{ }^{18} \mathrm{~F}$ bond.

\section{Conflicts of interest}

There are no conflicts to declare.

\section{Acknowledgements}

We thank the EPSRC and GE Healthcare for funding through a CASE studentship to F. M. M. (EP/L505651/1) and EPSRC for a doctoral prize (EP/R513325/1).

\section{References}

1 P. W. Miller, N. J. Long, R. Vilar and A. D. Gee, Angew. Chem., Int. Ed., 2008, 47, 8998.

2 J. D. G. Correia, A. Paulo, P. D. Raposinho and I. Santos, Dalton Trans., 2011, 40, 6144; R. Kumar, W. S. Shin, K. Sunwoo, W. Y. Kim, S. Koo, S. Bhuniya and J. S. Kim, Chem. Soc. Rev., 2015, 44, 6670.

3 G. E. Smith, H. L. Sladen, S. C. G. Biagini and P. J. Blower, Dalton Trans., 2011, 40, 6196; M. Glaser, P. Iveson, S. Hoppmann, B. Indrevoll, A. Wilson, J. Arukwe, A. Danikas, R. Bhalla and D. Hiscock, J. Nucl. Med., 2013, 54, 1981.

4 R. Ting, M. J. Adam, T. J. Ruth and D. M. Perrin, J. Am. Chem. Soc., 2005, 127, 13094; T. W. Hudnall and F. P. Gabbaï, J. Am. Chem. Soc., 2007, 129, 11978; A. Khoshnevisan, M. Jauregui-Osoro, K. Shaw, J. B. Torres, J. D. Young, N. K. Ramakrishnan, A. Jackson, G. E. Smith, A. Gee and P. J. Blower, EJNMMI Res., 2016, 6, 34; 
J. O’Doherty, M. Jauregui-Osoro, T. Brothwood, T. Szyszko, P. K. Marsden, M. J. O’Doherty, G. J. R. Cook, P. J. Blower and V. Lewington, J. Nucl. Med., 2017, 58, 1666; Z. Li, K. Chansaenpak, S. Liu, C. R. Wade, P. S. Conti and F. P. Gabbaï, MedChemComm, 2012, 3, 1305; K. Chansaenpak, M. Wang, Z. Wu, R. Zaman, Z. Li and F. P. Gabbaï, Chem. Commun., 2015, 51, 12439; Z. Liu, M. Pourghiasian, M. A. Radtke, J. Lau, J. Pan, G. M. Dias, D. Yapp, K. S. Lin, F. Bénard and D. M. Perrin, Angew. Chem., Int. Ed., 2014, 53, 11876.

5 P. Leverman, W. McBride, R. Sharkey, A. Eek, L. Joosten, W. Oyen, D. Goldenberg and O. Boerman, J. Nucl. Med., 2010, 50, 454; W. McBride, C. D’Souza, R. Sharkey, H. Karacay, E. Rossi, C. Chang and D. Goldenberg, Bioconjugate Chem., 2016, 21, 1331; W. McBride, R. Sharkey, H. Karacay, C. D’Souza, E. Rossi, P. Laverman, C. Chang, O. Boerman and D. Goldenberg, J. Nucl. Med., 2009, 50, 991; W. McBride, C. D'Souza, H. Karacay, R. Sherkey and D. Goldenberg, Bioconjugate Chem., 2012, 23, 538 .

6 W. Levason, S. K. Luthra, G. McRobbie, F. M. Monzittu and G. Reid, Dalton Trans., 2017, 46, 14519.

7 F. M. Monzittu, I. Khan, W. Levason, S. K. Luthra, G. McRobbie and G. Reid, Angew. Chem., Int. Ed., 2018, 57, 6658; R. Bhalla, W. Levason, S. K. Luthra, G. McRobbie, G. Sanderson and G. Reid, Chem. - Eur. J., 2015, 21, 4688; R. Bhalla, C. Darby, W. Levason, S. K. Luthra, G. McRobbie, G. Reid and G. Sanderson, Chem. Sci., 2014, 5,381 .

8 T. K. Venkatachalam, P. V. Bernhardt, D. H. R. Stimson, G. K. Pierens, R. Bhalla and D. C. Reutens, Aust. J. Chem., 2018, 71, 81.

9 G. Pascali, L. Matesic, B. Zhang, A. T. King, A. J. Robinson, A. T. Ung and B. H. Fraser, EJNMMI radiopharm. chem., 2017, 2, 9; A. Khoshnevisan, K. Chuamsaamarkkee, M. Boudjemeline, A. Jackson, G. E. Smith, A. D. Gee, G. D. Fruhwirth and P. J. Blower, J. Nucl. Med., 2017, 58, 156.

10 R. Schirrmacher, G. Bradtmoller, E. Schirrmacher, O. Thews, J. Tillmanns, T. Siessmeier, H. G. Buchholz, P. Bartenstein, B. Wängler, C. M. Niemeyer and K. Jurkschat, Angew. Chem., Int. Ed., 2006, 45, 6047; C. Wängler, B. Waser, A. Alke, L. Iovkova, H. G. Buchholz, S. Niedermoser, K. Jurkschat, C. Fottner, P. Bertenstein, R. Schirrmacher, J. C. Reubi, H. J. Wester and B. Wängler, Bioconjugate Chem., 2010, 21, 2289; S. Niedermoser, J. Chin, C. Wängler, A. Kostikov, V. Bernard-Gauthier, N. Vogler, J. P. Soucy, A. J. McEwan, R. Schirrmacher and B. Wängler, J. Nucl. Med., 2015, 56, 1100.

11 K. Chansaenpak, B. Vabre and F. P. Gabbaï, Chem. Soc. Rev., 2016, 45, 954; V. Bernard-Gauthier, J. J. Bailey, Z. Liu, B. Wängler, C. Wängler, K. Jurkschat, D. M. Perrin and R. Schirrmacher, Bioconjugate Chem., 2016, 27, 267; V. Bernard-Gauthier, M. L. Lepage, B. Waengler, J. J. Bailey, S. H. Liang, D. M. Perrin, N. Vasdev and R. Schirrmacher, J. Nucl. Med., 2018, 59, 568.
12 R. Bhalla, W. Levason, S. K. Luthra, G. McRobbie, F. M. Monzittu, J. Palmer, G. Reid, G. Sanderson and W. Zhang, Dalton Trans., 2015, 44, 9569.

13 E. Curnock, W. Levason, M. E. Light, S. K. Luthra, G. McRobbie, F. M. Monzittu, G. Reid and R. N. Williams, Dalton Trans., 2018, 47, 6059.

14 P. Knopp and K. Wieghardt, Z. Naturforsch., 1991, 46b, 1077.

15 S. L. Benjamin, W. Levason and G. Reid, Chem. Soc. Rev., 2013, 42, 1460.

16 D. A. House and V. McKee, Polyhedron, 1993, 12, 2335; J. V. Brencic, B. Ceh and I. Leban, Monatsh. Chem., 1981, 12, 1359; J. Glerup, J. Josephsen, K. Michelsen, E. Pedersen and C. E. Schaffer, Acta Chem. Scand., 1970, 24, 247; J. V. Brencic and I. Leban, Z. Anorg. Allg. Chem., 1981, 480, 213; J. W. Vaughn and J. Marzowski, Inorg. Chem., 1973, 12, 2346; J. W. Vaughn, Inorg. Chem., 1981, 20, 2397; H. L. Schlaefer, H. Gausmann and H. U. Zander, Inorg. Chem., 1967, 6, 1528; C. E. Schaffer, J. M. Lang and H. G. Drickamer, Inorg. Chem., 1996, 35, 5072.

17 A. B. P. Lever, Inorganic Electronic Spectroscopy, Elsevier, Amsterdam, 1984.

18 H. X. Liu, Acta Crystallogr., Sect. E: Struct. Rep. Online, 2013, 65, m1093.

19 K. S. Pedersen, G. Lorusso, J. J. Morales, T. Weyhermuller, S. Piligkos, S. K. Singh, D. Larsen, M. Schau-Magnussen, G. Rajaraman, M. Evangelisti and J. Bendix, Angew. Chem., Int. Ed., 2014, 53, 2394.

20 T. Birk, M. J. Magnussen, S. Piligkos, H. Weihe, A. Holten and J. Bendix, J. Fluorine Chem., 2010, 131, 898.

21 J. H. Choi and U. Lee, Acta Crystallogr., Sect. E: Struct. Rep. Online, 2008, 64, m1186; J. H. Choi, I. G. Oh, K. S. Ryoo, W. T. Lim, Y. C. Park and M. H. Habibi, Spectrochim. Acta, Part A, 2006, 65, 1138.

22 P. Nunez, C. Elias, J. Fuentes, X. Solans, A. Tressaud, M. C. M. DeLucas and F. Rodriguez, J. Chem. Soc., Dalton Trans., 1997, 4335.

23 A. R. Biju and M. V. Rajasekharan, J. Mol. Struct., 2008, 875, 456.

24 C. Mantel, S. K. Hassan, J. Pecaut, A. Deronzier, M. N. Collomb and C. Duboc-Toia, J. Am. Chem. Soc., 2003, 125, 12337.

25 K. S. Pedersen, M. Sigrist, H. Weihe, A. D. Bond, C. A. Thuesen, K. P. Simonsen, T. Birk, H. Mutka, A. L. Barra and J. Bendix, Inorg. Chem., 2014, 53, 5013.

26 K. S. Pedersen, M. A. Sorensen and J. Bendix, Coord. Chem. Rev., 2015, 299, 1.

27 F. Kraus and S. A. Baer, Z. Naturforsch., B: J. Chem. Sci., 2011, 66, 865.

28 J. A. McCleverty and T. J. Meyer, Comprehensive Coordination Chemistry II, Elsevier, Oxford, 2004, vol. 6.

29 Y. Mitsutsuka, E. Tursun and M. Nakahara, Bull. Chem. Soc.Jpn., 1990, 63, 260.

30 E. F. Murphy, R. Murugavel and H. W. Roesky, Chem. Rev., 1997, 97, 3425; N. M. Doherty and N. W. Hoffman, Chem. 
Rev., 1991, 91, 553; W. Massa and D. Babel, Chem. Rev., 32 J. Mason, Multinuclear NMR, Plenum, New York, 1987. 1988, 88, 275; M. J. Molski and K. Seppelt, Dalton Trans., 33 N. Juranic, J. Chem. Soc., Dalton Trans., $1984,1537$.

2009, 3379; M. Leblanc, V. Maisonneuve and A. Tressaud, 34 S. Bagger and H. P. Jensen, Acta Chem. Scand., 1978, 32, Chem. Rev., 2015, 115, 1191.

31 B. N. Figgis and J. Lewis, Prog. Inorg. Chem., 1967, 6, 37. 659; T. Laier, C. E. Schaffer and J. Springborg, Acta Chem. Scand., 1980, 34, 343. 